\title{
Regeneration status and species diversity of major tree species under scientific forest management in Kapilbastu district, Nepal
}

\author{
B. Aryal๑ ${ }^{1}$, S. Regmi $\odot^{2 *}$ and S. Timilsina $\odot^{3}$
}

Received : 12, July, 2021

Revised : 22, November, 2021 Accepted : 23, December, 2021 Published : 31, December, 2021

In Nepal, scientific forest management has been practiced as an effective forest management technique to utilize forest resources sustainable. However, the program has faced many controversies such as intentional logging of only high-valued timber species like Shorea robusta. In addition, few believe this program is severely affecting the regeneration productivity and species diversity in the natural forests. In order to address these issues, we examined the regeneration condition and plant species diversity in the stands where scientific forest management operations were carried out. The data related to regeneration status and species diversity were collected using a systematic random sampling of the selected stands. Our results showed good regeneration conditions (Seedling $>5000$, Sapling $>2000$ ) in all the studied stands. The tree species community was dominated by S. robusta (Sal) followed by Schleichera oleosa (Kusum) and Casia fistula (Rajbriksha). The value of diversity indices of different species varied significantly between felling series. The highest diversity was found in the second year felling series with the Simpsons Index of dominance value 0.6934 and the lowest species diversity was in the first year felling series with a value of 0.8448 . It can be recommended that the regeneration felling practice has helped in promoting the regeneration condition and growth.

Keywords: Regeneration, scientific forest management, Shorea robusta, silvicultural treatment.

$\mathrm{N}$ epal consists of a total of 5.96 million ha i. e. $40.36 \%$ forest area (DFRS, 2015).

There was no robust management of productive forests in the past due to the centralized institution structure of forest management in Nepal (Paudyal, 2007). The management was based on the annual allowable cut principle in which a single selection silvicultural system was applied for harvesting. Recently, the government of Nepal has started promoting Scientific Forest Management (SciFM) describing "an application of a appropriate silvicultural system and forest management principles through design of systematic compartments of fixed rotation age". This highlights the use of shelterwood silviculture system with very high intensity logging, leaving only 15-30 mature mother trees per ha to address inactive forest management, suboptimal forest production, and forest health degradation (Bhattarai et al., 2018; Poudel, 2018). At present, it has been implemented by 285 Community Forest User Groups (CFUGs) across Nepal (Baral \& Dhakal, 2018). Since its pilot implementation in Tilourakot Collaborative Forest, SciFM now has been expanded to 30 collaborative forests, 285 community forests and seven government block forests (Baral \& Dhakal, 2018). As of 2020, around 121,852 ha of forests are currently being managed scientifically using SciFM principles both within collaborative forests and community forests in 52 districts of the nation (Bhandari \& Lamichhane, 2020). The regeneration and

1 Agriculture and Forestry University, Faculty of Forestry, Hetauda, Nepal

2 Tribhuvan University (TU), Institute of Forestry (IOF), Hetauda, Nepal. *E-mail: iregmisid@gmail. com

3 TU, IOF, Pokhara, Nepal. 
community-level species richness of both seedlings and saplings increases under active forest management (Subedi et al., 2018). The forest management activities benefit the forest with improved regeneration (Malik \& Bhatt, 2015), greater species diversity and richness (Poudyal et al., 2020), and ultimately leading to sustainability (Pokharel et al., 2015) if followed in prescribed way. In forest management, regeneration study not only depicts the current status but also hints about the possible changes in forest composition in the future (Malik \& Bhatt, 2016). Also, species is one of the major analytical characteristics of the plant community (Malik et al., 2014). Knowledge of species composition and diversity of tree species is of utmost importance not only to understand the structure of a forest community but also for planning and implementation of conservation strategy of the community (Malik \& Bhatt, 2015). Assessment of forest community composition and structure is very helpful in understanding the status of tree populations, regeneration, and diversity for conservation purposes (Mishra et al., 2013). The species richness and diversity of trees are fundamental to total forest biodiversity because trees provide resources and habitat for almost all other forest species (Malik, 2014).

The forests of lowland Nepal are prone to many calamities like fire, grazing, and flood. The most

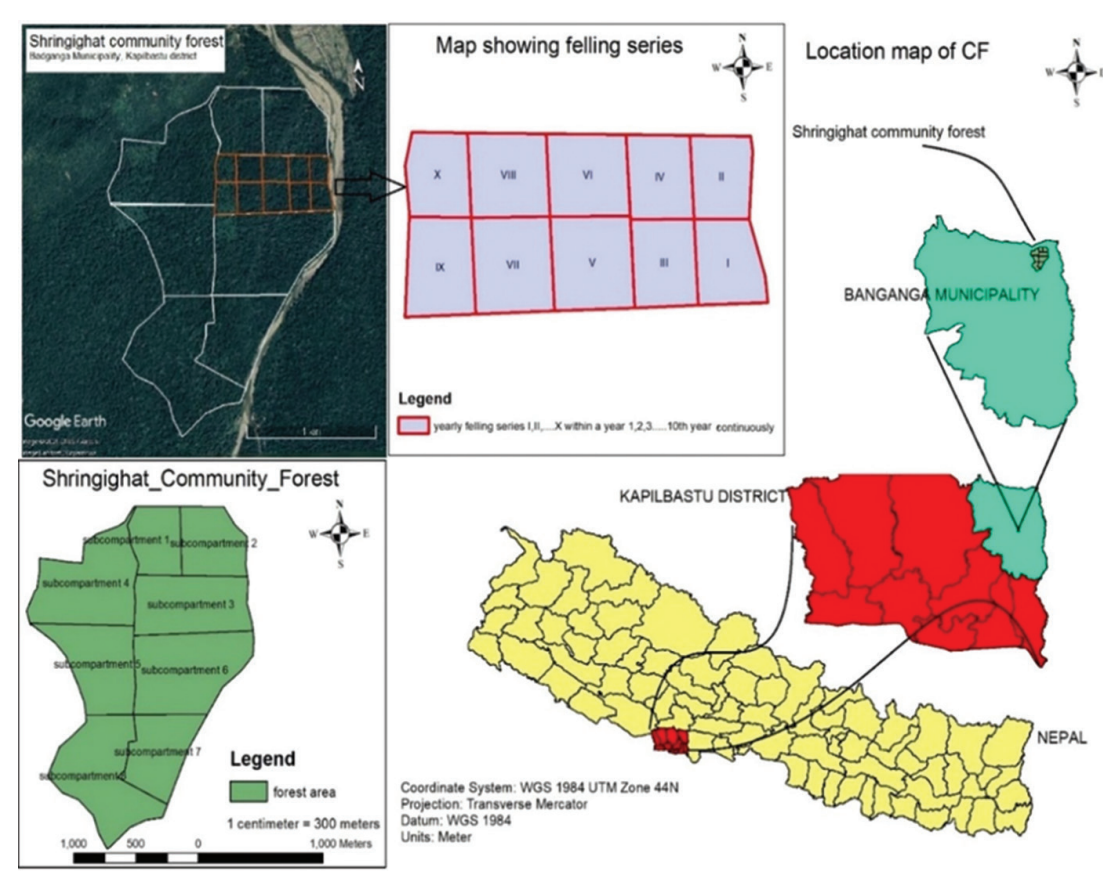

Figure 1: Map showing the location of the study area affected plant communities by these calamities are regenerations and young trees. Enough knowledge and study in forest characteristics of different tree species is essential to guarantee forest's natural regeneration (Mousavi et al., 2011). Several researchers (Hull et al., 2010; Sunam et al., 2013; Baral et al., 2018; Basnyat et al., 2018a; Basnyat et al., 2018b) define SciFM as a tool having complex mechanism which promotes centralization of forest disfavoring forest users in Nepal. It is also explained as the name of active utilization implemented without considering institutional aspects (Paudel et al., 2018). The government has announced to discontinue SciFM practice in June 2019 stating the excessive logging of only high-valued tree species like Shorea robusta which results in lowering and decling the plant diversity and regeneration status, respectively. The long-term effects of SciFM on plant species and regeneration conditions are not studied well. Most of the studies are concerned with livelihood impact on SciFM. There has been significant increment in the regeneration per hectares after implementing the SciFM program in this study area that makes it as an ideal location to assess the success or failure of SciFM program. Therefore, this study was carried out to assess the regeneration status and plant species diversity of major tree species after felling of the stands in SciFM.

\section{Materials and methods}

\section{Study area}

The study was carried out in the Shringigh at Community Forest (CF) which is located in Badganga Municipality of Kapilbastu district in the western Terai region of Nepal in 2019 (Figure 1). The Shringigh at CF covers an area of 499. 26 ha, and is located between $27^{\circ} 44^{\prime} 13$. $2^{\prime \prime}-27^{\circ} 45^{\prime} 14$. 1"N latitudes and $83^{\circ} 11^{\prime} 27$. $8^{\prime \prime}-83^{\circ} 11^{\prime} 57$. 5 "Elongitudes. The elevation of the study area ranges from $190 \mathrm{~m}$ to $200 \mathrm{~m}$ above the mean sea level. This forest is dominated by Sal (S. robusta) 
associated with Asna (Terminalia alata), Karma (Adina cordifolia), Kusum (Schleichera oleosa), Satisal (Dalbergia latifolia), Rohini (Mallotus philippensis), Kutmero (Litsea polyantha), Bel (Aegle marmelos), etc. The major soil types found here are clayey loam, alluvium, and rocky types of soil. The forest is managed under an Irregular Shelterwood Silvicultural System. Altogether, 2,480 households are benefited from this Community Forest.

\section{Data Collection}

The data was collected using a systematic random sampling method. The vegetation sampling data were collected from a total of 40 concentric circular sample plots (CCSPs) of $10 \mathrm{~m}$ radius spaced at $50 \mathrm{~m}$ (Figure 2, Aryal et al., 2017). Further, the data on the plant species diversity were also collected from each of sample plot. The sample plots were overlaid on the map using the fishnet tool in ArcGIS 10. 4. 1, and the GPS coordinates of the plots were extracted. Each plot was located in the field with the help of Garmin GPS device. The total number of sample plots was determined in accordance with the total felling area, and resource inventory was carried out with a sampling intensity of $1 \%$ as per the Community Forest Inventory Guidelines 2061 (DOF, 2004).

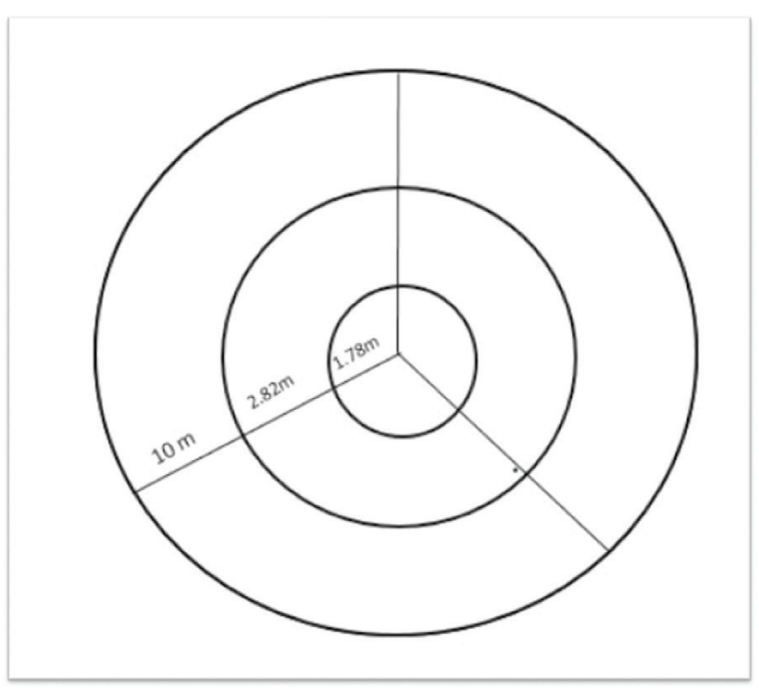

Figure 2: A concentric circular sample plot

The number of tree species $(\geq 10 \mathrm{~cm}$ DBH) were counted in the main plot of $10 \mathrm{~m}$ radius. To gather data on regeneration, individual plants were categorized into seedlings (height $<1.3 \mathrm{~m}$ ), and saplings (height $>1.3 \mathrm{~m}$ and $<10 \mathrm{~cm} \mathrm{DBH}$ ). The study was conducted in those periodic blocks where regeneration felling operation was carried out, and the areas were mapped out using ArcGIS 10. 4. 1. The seedlings and saplings within $1.78 \mathrm{~m}$ and $2.82 \mathrm{~m}$ radii in each CCSP (Subedi et al., 2010) were counted and noted. The density per hectare of each species was calculated to determine their regeneration status in the managed coup. Table 1 shows the area and the total number of sample plots in different felling series.

Table 1: No. of sample plots vs. Area of different felling series

\begin{tabular}{lll}
\hline Felling Series & $\begin{array}{l}\text { Area } \\
\text { (ha) }\end{array}$ & $\begin{array}{l}\text { No. of sample } \\
\text { plots }\end{array}$ \\
\hline First-year & 3.43 & 15 \\
Second-year & 3.82 & 15 \\
Third-year & 2.86 & 14 \\
Fourth-year & 3.76 & 16 \\
Total & $\mathbf{1 3 . 8 7}$ & $\mathbf{6 0}$ \\
\hline
\end{tabular}

\section{Data analysis}

ArcGIS10.4.1Software was used for the proximity of establishing sample plots and map preparation. The data were processed and analyzed using MS Excel. The number of seedlings and saplings of S. robusta and other species per hectare were calculated, and their status and forest condition were analyzed as per the CF Inventory Guidelines 2061 (DOF, 2004). The density of each species per hectare was calculated using the formula:

Species density per hectare $=\frac{\text { Total no. of seedlings and saplings }}{\text { Area of sample plot }} \times 10000$

The condition of different felling series were assessed on the basis of the total number of seedlings and saplings of different tree species per hectare found in the respective felling series. As per the CF Inventory Guidelines 2061 (DOF, 2004), the condition of the forest is 'good' if the numbers of seedlings and saplings exceed 5,000 and 2,000 per hectare. Similarly, the condition of the forest is 'medium' if the numbers of seedlings and saplings occur between 2,000-5,000 and 800-2,000 per hectare; and 'poor' if the numbers 
of seedlings and saplings occur below 2,000 and 800 per hectare, respectively (Table 2 ).

Table 2: Condition of forest based on regeneration status

\begin{tabular}{llll}
\hline Plant Type & \multicolumn{4}{l}{ No. per hectare } & \\
\hline Seedling & $>5,000$ & $2,000-5,000$ & $<2,000$ \\
Sapling & $>2,000$ & $800-2,000$ & $<800$ \\
\hline $\begin{array}{l}\text { Condition of } \\
\text { Forest }\end{array}$ & Good & Medium & Poor \\
\hline
\end{tabular}

Source: CF Inventory Guidelines, 2061 (DOF, 2004).

\section{Plant diversity}

Species diversity refers to the frequency and variety of species within a geographical area (Malik et al., 2014). It is the combination of species richness and species evenness. Species richness is the total number of species per sampling unit, and this makes no use of relative abundances. Species evenness is the distribution of individuals among the species. Species diversity can be expressed in a single number which can be used to assess the diversity of any population in which each member belongs to unique species. The plant diversity was measured using the following diversity indices:

a) The concentration of dominance was measured using the Simpson's Index which is mathematically expressed as-

Simpson's Index of Dominance $(D)=\sum_{i=1}^{S}(p i)^{2}$

Where ' $S$ ' is the total number of species, 'pi' is the proportion of all individuals that belong to species ' $i$ ' in the sample. The value of ' $D$ ' ranges between 0 and 1. The value near zero corresponds to higher diversity or heterogeneous community while the value near one relates to a more homogeneous community.

b) The Simpson Index of Diversity is calculated by subtracting Simpson's Index of Dominance from 1, i. e.

Simpson Index of Diversity $=1-D$ where, 'D' is the Simpson Index of Dominance the value of which also rages between 0 and 1 ; the greater the value, the more the sample diversity.

c) Shannon-Wiener Diversity Index (Shannon, 1948) was used for the calculation of species diversity. Mathematically, it is expressed as:

Shannon-Wiener Diversity Index $(\mathrm{H})=-\sum_{i-1}^{S}(P i)(\ln P i)$

where, ' $S^{\prime}$ is the total number of species in the sample, ' $P i^{\prime}$ is the proportion of all individuals that are of species ' $i$ '. The Shannon Index increases as both the richness and the evenness of the community increase.

d) Species richness index (d) indicates the mean number of species per sample (Margalef, 1958), and is expressed as:

$\mathrm{d}=\frac{s-1}{\ln N} \ldots \ldots \ldots$

where ' $\mathrm{d}$ ' is the species richness index, $\mathrm{S}$ is the number of species and $\mathrm{N}$ is the number of individuals of all species.

e) Equitability or evenness index (e) refers to the degree of the relative dominance of each species in that area. Mathematically, it is expressed as:

$\mathrm{e}=\frac{H}{\ln S}$.

where ' $\mathrm{e}$ ' is the evenness, ' $\mathrm{H}$ ' is the ShannonWiener's Diversity Index and ' $S$ ' is the number of species. The value of e ranges from 0 (not even) to 1 (completely even).

\section{Results}

\section{Regeneration status}

The quantitative structures of regeneration of different tree species in the different felling series were studied based on the count of their seedlings and saplings in the sample plots. Table 1depicts the area and the total number of sample plots in different felling series while Table 3 shows the number of seedlings and saplings of different species in the sample plots of different felling 
Table 3: Total count of regenerations of different species in the sample plots

\begin{tabular}{|c|c|c|c|c|c|c|c|c|}
\hline \multirow[b]{3}{*}{ Species } & \multicolumn{8}{|c|}{ Felling Series } \\
\hline & \multicolumn{2}{|c|}{$\begin{array}{l}1^{\text {st }} \text { yr. Felling } \\
\text { Series }\end{array}$} & \multicolumn{2}{|c|}{$\begin{array}{l}2^{\text {nd }} \text { yr. Felling } \\
\text { Series }\end{array}$} & \multicolumn{2}{|c|}{$\begin{array}{l}3^{\text {rd }} \text { yr. Felling } \\
\text { Series }\end{array}$} & \multicolumn{2}{|c|}{$\begin{array}{l}4^{\text {th }} \text { yr. Felling } \\
\text { Series }\end{array}$} \\
\hline & ¿ே0 & 它 & 它 & 它 & 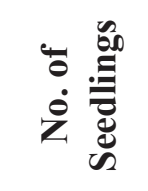 & 它 & 它葛 & 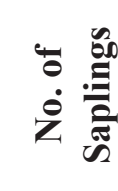 \\
\hline S. robusta & 150 & 230 & 239 & 289 & 185 & 260 & 381 & 275 \\
\hline S. oleosa & 10 & 0 & 9 & 0 & 11 & 0 & 5 & 1 \\
\hline C. fistula & 5 & 0 & 0 & 0 & 7 & 0 & 2 & 2 \\
\hline D. latifolia & 0 & 3 & 8 & 0 & 2 & 0 & 0 & 0 \\
\hline T. alata & 0 & 0 & 8 & 10 & 0 & 0 & 0 & 3 \\
\hline A. cordifolia & 0 & 0 & 6 & 0 & 23 & 0 & 1 & 0 \\
\hline Others & 16 & 0 & 70 & 11 & 16 & 6 & 62 & 0 \\
\hline Total & 181 & 233 & 332 & 310 & 244 & 266 & 451 & 281 \\
\hline
\end{tabular}

Source: Field Inventory, 2019.

series counted during the inventory process. The regeneration count of S. robusta was found to be the highest among all the other species present in all the felling series.

The numbers of seedlings and saplings of different species per hectare were determined based on their regeneration counting in the sample plots. S. robusta had the highest number of seedlings and saplings per ha in all the felling series as compared to those of all the other tree species. The regeneration status of different species are highlighted in Figures 3-6with respect to their felling series.

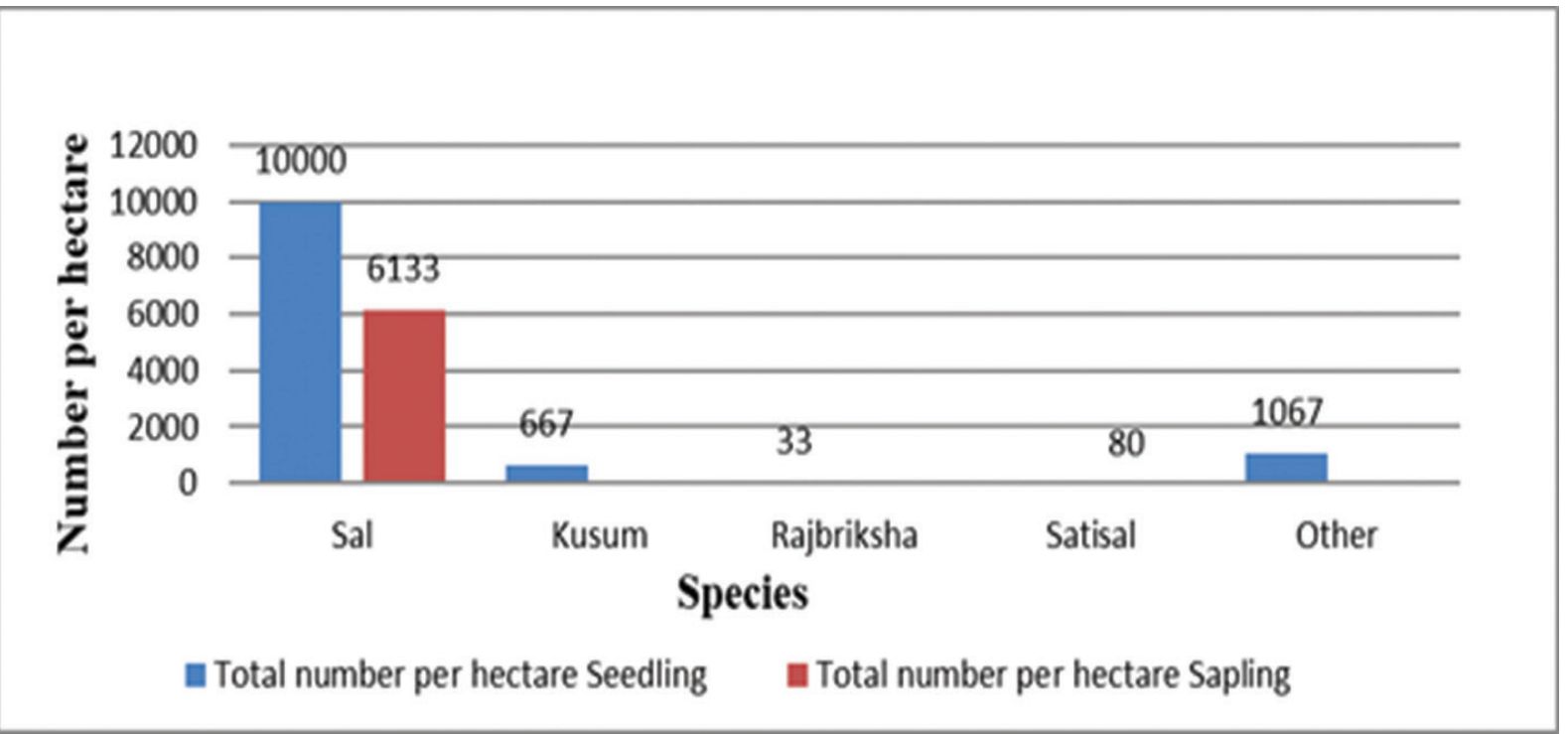

Figure 3: Regeneration status of seedlings and saplings of different. spp. in the $1^{\text {st }}$ Yr. Felling Series 


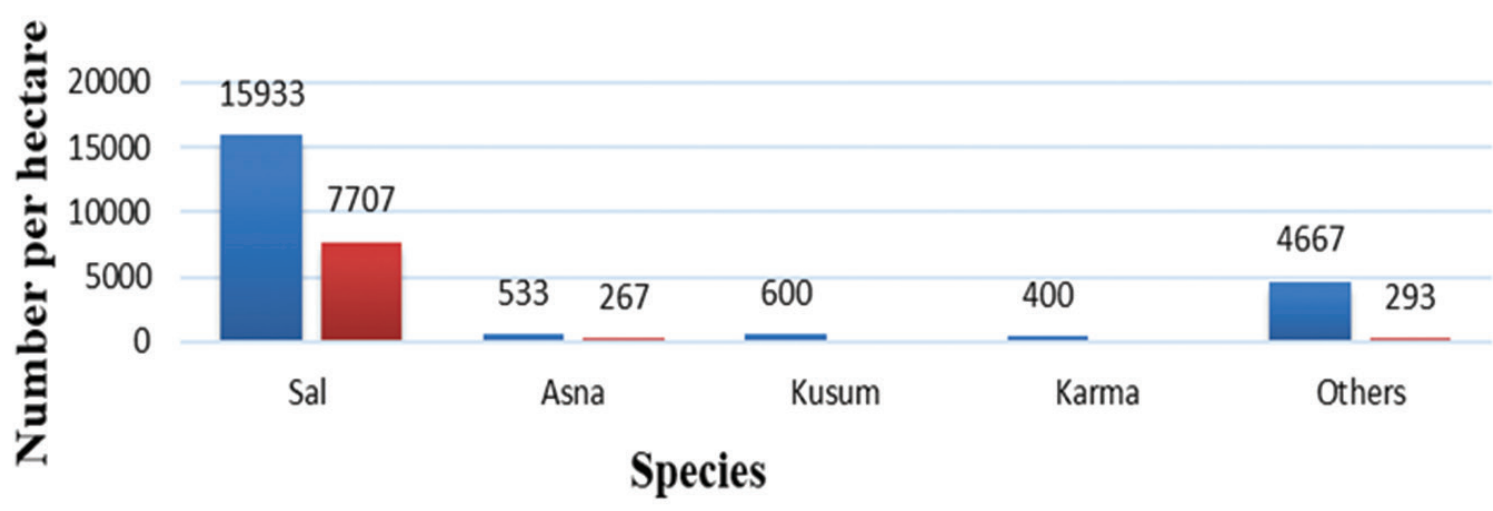

घ Total number per hectare Seedlings @ Total number per hectare Saplings

Figure. 4: Regeneration status of seedlings and saplings of different spp. in $2^{\text {nd }}$ Yr. Felling Series

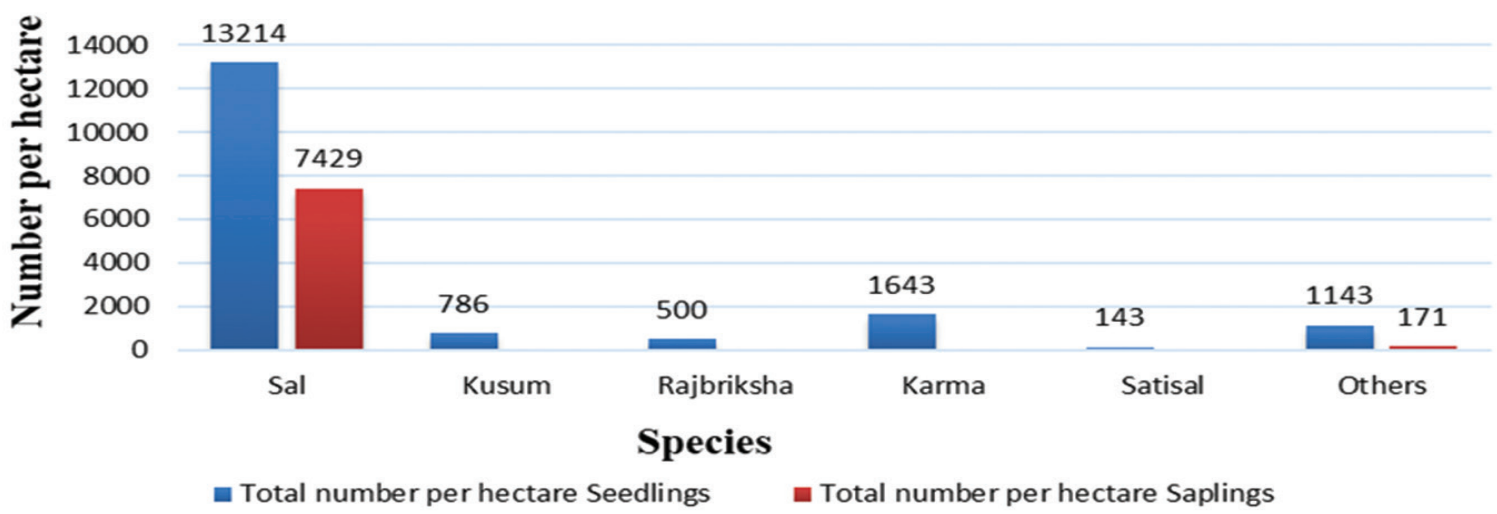

Figure 5: Regeneration status of seedlings and saplings of different spp. in the $3^{\text {rd }}$ Yr. Felling Series

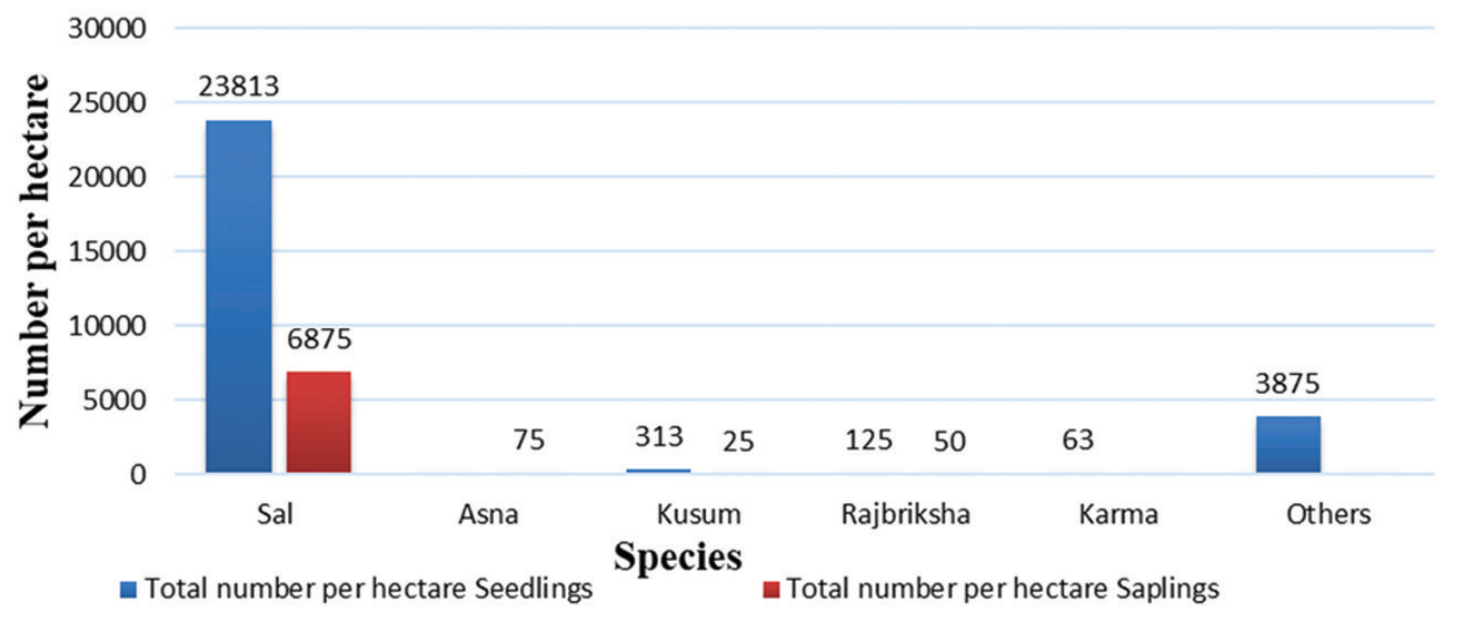

Figure 6: Regeneration status of seedlings and saplings of different spp. in the $4^{\text {th }}$ Yr. Felling Series 


\section{Regeneration status of different felling series}

Table 6 below depicts the regeneration status of different felling series.

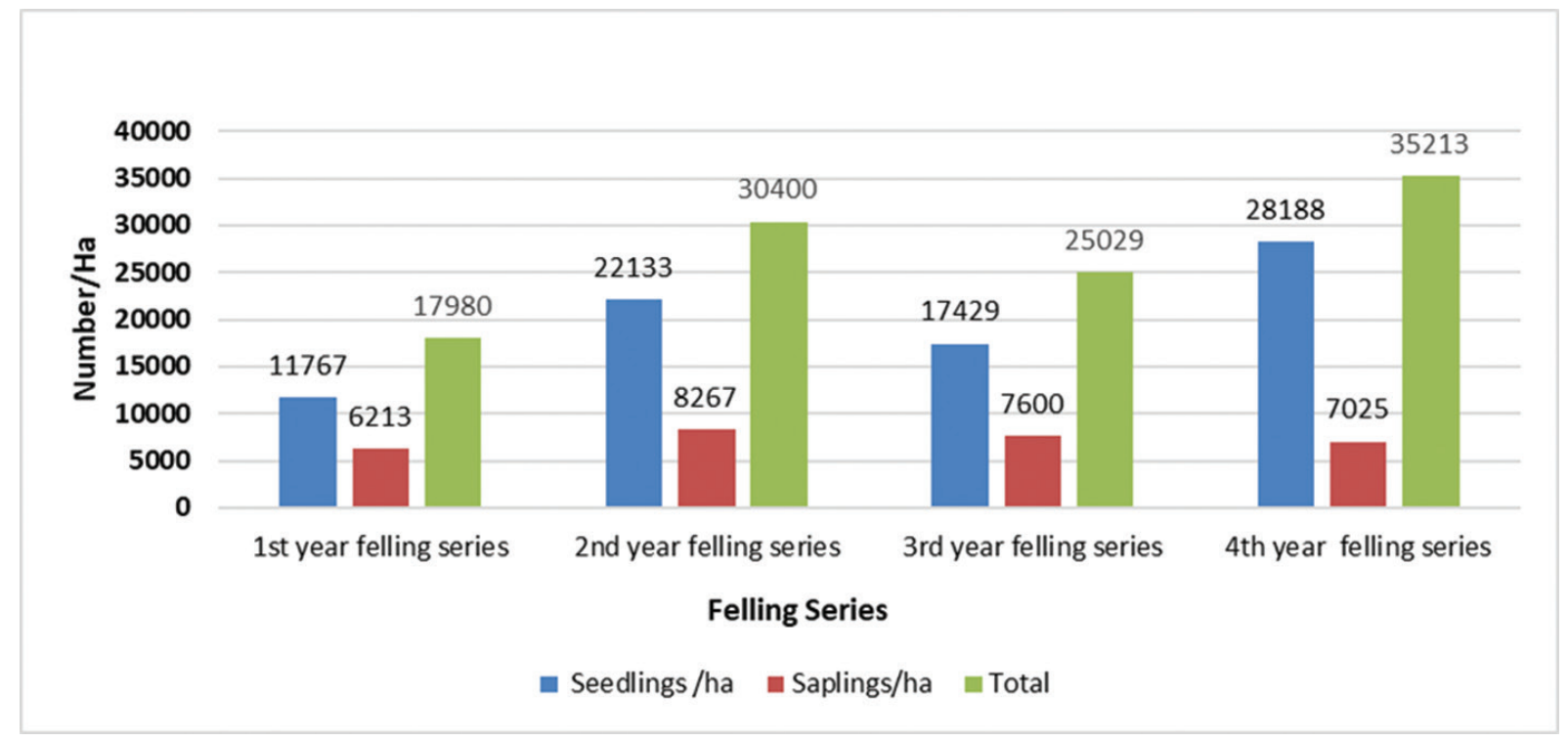

Figure 7: Regeneration status of different felling series

The total number of seedlings $(28,188 / \mathrm{ha})$ and saplings $(7,025 / \mathrm{ha})$ combined per ha was found to be the highest $(35,213)$ in the $4^{\text {th }}$ Year Felling Series. In this Felling Series, S. robusta possessed the highest number of seedlings $(15,933)$ and saplings $(6,875)$ per ha while $A$. cordifolia had the least (only 63 seedlings per ha, Figure 6).

The $2^{\text {nd }}$ Year Felling Series had the second highest number of seedlings $(22,133 /$ ha) and saplings $(8,267 /$ ha) combined $(30,400)$ per ha. In this Felling Series, the highest number of seedlings $(23,813)$ and saplings $(7,707)$ per ha were belonged to $S$. robusta while A. cordifolia consisted of the least (just 400 seedlings per ha, Figure 4).

Similarly, the third highest number of seedlings $(17,429 / \mathrm{ha})$ and saplings $(7,600 / \mathrm{ha})$ combined $(25,029)$ per ha was noticed in the $3^{\text {rd }}$ Year Felling Series. This Felling Series also possessed S. roubsta as the dominant species with 13,214 seedlings per ha and 7,429 saplings per ha; D. latifolia consisted of merely 143 seedlings per ha (Figure 5).

The 1stYear Felling Series consisted of the least number of seedlings $(11,767 / \mathrm{ha})$ and saplings 6,213/ha) combined (17,980/ha) per ha. S. roubsta possessed the highest number of seedlings
$(10,000 /$ ha $)$ and saplings (6,113/ha) whereas C. fistula occupied the least (just 33 seedlings per ha, Figure 3).

Figure 7 shows the summary of regeneration status in different felling series.

As per the CF Inventory Guidelines 2061, the regeneration status of all the felling series were found to be in good condition with the number of seedlings and saplings exceeding 5,000 and 2,000 per ha, respectively.

\section{Diversity of plant species}

Table 4 shows a different scenario of the plant diversity indices. Comparing the diversity indices among the four felling series, the value of the Simpson's Index $(0.6934)$ in the $2^{\text {nd }}$ Year Felling Series was more near to ' 0 'which indicated that it was more diverse as compared to the other felling series. Also, the value of the Shanon Weiner Index (0. 6255) was higher in the $2^{\text {nd }}$ Year Felling Series in comparison with those of the other felling series which also supported the result of the Simpson Index. In the case of the species evenness, the value was found to be greater $(0.3869)$ in the $2^{\text {nd }} Y e a r$ Felling Series which depicted that the species were more evenly distributed in this series as compared to the other felling series. 
Table 4: Plant diversity indices in different felling series

\begin{tabular}{lllllll}
\hline $\begin{array}{l}\text { Felling } \\
\text { Series }\end{array}$ & $\begin{array}{l}\text { No. of } \\
\text { species }\end{array}$ & $\begin{array}{l}\text { Simpson's Index } \\
\text { of Dominace (D) }\end{array}$ & $\begin{array}{l}\text { Shannon Wiener } \\
\text { Index (H) }\end{array}$ & $\begin{array}{l}\text { Simpson's } \\
\text { Index of } \\
\text { Diversity (1-D) }\end{array}$ & $\begin{array}{l}\text { Species } \\
\text { Richness } \\
\text { Index (d) }\end{array}$ & $\begin{array}{l}\text { Evenness } \\
\text { Index (e) }\end{array}$ \\
\hline $1^{\text {st } Y e a r ~}$ & 6 & 0.8448 & 0.3833 & 0.1552 & 0.8298 & 0.2139 \\
$2^{\text {nd }}$ Year & 6 & 0.6934 & 0.6255 & 0.3066 & 0.7734 & 0.3869 \\
$3^{\text {rd }}$ Year & 7 & 0.7663 & 0.5072 & 0.2337 & 0.9624 & 0.2606 \\
$4^{\text {th }}$ Year & 7 & 0.8104 & 0.4071 & 0.1896 & 0.9097 & 0.2092 \\
\hline
\end{tabular}

Source: Field Inventory, 2019.

Similarly, the species richness index was greater (0. 9624) in the $3^{\text {rd }}$ Year Felling Series which possessed total of seven species. The $4^{\text {th }}$ Year Felling Series also consisted of seven species, but hada comparatively lower value of the species richness index (0.9097) which could be due to the difference in the abundance of the species in those two felling series. However, if the values of all the plant diversity indices were analysed independently without comparing one felling series with another, then we could relate that there was no suitable plant diversity maintained in all the felling series as the dominance of a single species ( $S$. robusta) was found to be more in all felling areas. It can be noticed from Figures 3, $4,5 \& 6$ and Table 3that there is a homogeneous type of regeneration in all the felling series.

\section{Discussion}

Natural regeneration of plant species is crucial to the sustainable management of tropical forests (Medjibe et al., 2014). Therefore, knowledge about the plant regeneration procedure and dynamics is essential to plan and implement the management activities in the forest (Mwavu \& Witkowski, 2009; Puhlick et al., 2012; Yang et al., 2014). This study revealed the number of regenerating species and plant diversity in the Shringighat CF. The study found that executing SciFMin community forests safeguards the promising forest health in terms of substantial regeneration of demanded species, $S$. robusta in the lowland region of Nepal. In all the felling series, S. robusta was found to be the dominant species, which is similar to the findings of the Terai forest inventory during 2010-2012 (DFRS, 2015). The same results was reported by Giri et al. (1999); Paudyal (2013); Acharya et al.
(2009); Sapkota et al. (2009). After S. robusta, the dominance of other species was found to be different in the different felling series (see Figure $3,4,5 \& 6)$.

The study found higher seedlings and saplings number in this CF; it could be the result of regeneration felling in the Shringighat Community Forest. The numbers of seedlings were found to be $11,767 /$ ha in the $1^{\text {st }}$ Year Felling Series, 22,133/ha in the $2^{\text {nd }}$ Year Felling Series, 17,429/ha in the $3^{\text {rd }}$ Year Felling Series, and 28,188 /ha in the $4^{\text {th }}$ Year Felling Series. On an average, there were 19,879 seedlings per ha in all the felling series which corresponds to the results of Awasthi et al. (2015) who found 16,555-21,000 seedlings per ha after regeneration felling of $S$. robusta forest under irregular shelterwood system in a similar site of Rupandehi district. Similarly, there were 6,213 saplings per ha in the $1^{\text {st }}$ Year Felling Series, 8,267 per ha in the $2^{\text {nd }}$ Year Felling Series, 7,600 per ha in the $3^{\text {rd }}$ Year Felling Series, and 7,025 per ha in the $4^{\text {th }}$ Year Felling Series with $S$. robusta as the dominant species. As per the Community Forest Inventory Guidelines 2061, the status of regeneration (good, satisfactory, poor), the densities of the seedlings and saplings were found to be 'good' in all the four felling series. The difference in regeneration status in the different felling series may be due to the differences in the intensity of grazing, logging, cleaning operations, and the growth of invasive species in the different felling areas. A number of researchers such as Gautam et al. (2002); Sakurai et al. (2004); Yadav et al. (2003) have stated that the prohibition of controlled grazing inside CFs in Nepal is to contribute positive ecological impacts of the CF program, which ultimately increases forest cover, stem density, and natural regeneration. A 
study carried out by Buffum et al. (2009) also sorted the overall increase in seedling and sapling density to the reduced grazing intensity in a late successional broadleaved community forest in Bhutan. Similarly, the impact of logging on tree regeneration varied with size and disturbance intensity. When the disturbances were immediate in intensity, the diversity of natural regeneration was highest whereas, pioneer tree species proliferated in the more heavily disturbed areas (de Carvalho et al., 2017). A study conducted by Baniya et al. (2019) in Pine forest has also recommended that, the regeneration status and normal growing stock can be enhanced if the thinning and felling is carried out annually in different compartments in different CFs. Invasive Tree Species (ITS) might influence natural regeneration by directly limiting the saplings of native species (Hejda et al., 2017). The ITS shed large numbers of seeds below their canopies, and there exists competition for light and soil resources (Kawaletz et al., 2014). Hence, it affects regeneration too.

From long ago, species richness, various diversity indices, stem density and species importance value index has been used to evaluate population dynamics and their diversity in the forest (Gimaret-Carpentier et al., 1998). Different types of forest management practices significantly affect the structure of plant species diversity in forests (de Avila et al., 2015). However, the script of the management objectives also plays a crucial part in determining plant diversity and species richness in the long-term (Cedamon et al., 2017). Species diversity refers to the frequency and variety of species within a geographical area (HMGN/ MFSC, 2002). It refers to the species richness and evenness within an area which describes the structure of the plant community. Plant species are directly affected by the harvesting or management practices operated in a stand. This study showed the dominance of single species was higher,i. e. 0.69 to 0.84 . Subsequently, the diversity index was low in all the four felling series. The Simpson Species Diversity Index was found to be less in all the four felling seriesi. e. between 0.15 to 0. 30. Awasthi et al. (2020) also concluded that the silvicultural practices under SciFM decreases plant diversity as the species diversity index was found to have decreased in all the managed blocks than in the unmanaged ones. The Shannon-Wiener Index was found to be between 0.38 to 0.62 . As these four felling series can be considered as managed forests, the present values are closely comparable to those reported by Uniyal et al. (2010) from Garhwal Himalaya, where it was 0.7 for the managed forests and 1. 4 for the unmanaged ones. Also, the species richness and species evenness were found to be comparatively low in this study; the species richness was found to be between 0.77 to 0.96 while the species evenness was found to be within the range of $0.20-0.36$ which could be due to the harvesting and logging practices in the felling series. Harvesting operations and logging intensity are accounted to be decidedly effectual in shaping species diversity and composition (González-Alday et al., 2008). For example, the higher the harvesting quantity, the lesser the species diversity in SciFM practices (Shima et al., 2018). The cause of lowering species diversity, evenness, and richness in managed blocks is also accounted for the proportionately higher logging intensity in SciFM, where just 15-30 mother trees per hectare are kept during regeneration felling in the forest (Poudyal et al., 2019). The species richness indices in the $1^{\text {st }}$, $2^{\text {nd }}, 3^{\text {rd }}$ and $4^{\text {th }}$ Year Felling Series in this study were found to be $0.8298,0.7734,0.9624$, and 0. 9097, respectively, indicating less species richness in our study site. A study conducted by Halpern \& Spies (1995) and Smith et al. (2005) reveled the declining of species richness due to high logging intensity in the sub-tropical forests of Australia. Our findings also indicated positive impacts towards regeneration status in different felling series but with less species diversity. Several researchers such as CarreñoRocabado et al., 2012; Smith et al., 2005; and Roberts \& Gilliam, 1995) have argued that there is less species diversity in intensively managed production forestry than natural forest. The study performed by Sapkota et al. (2010) also found the significant decline in the species diversity along the disturbance gradient in $S$. robutsa forest in Nepal. The additional management activities like fertilization, grazing, and herbicide application could also affect the species composition and diversity of vegetation in addition to the initial effect of logging and preparation of site. Shima 
et al. (2018) concluded that species diversity increased with the decreasing logging intensity in Malaysia suggesting that the active management activities and logging practices in forests would change the species composition with due regards of changes in species mortality and recruitment.

\section{Conclusion}

This study conducted a comparative analysis about the regeneration status and species diversity in different felling series of the Shringigh at CF where SciFM was practiced. We found that SciFM resulted in homogeneity of the tree species and increased the number of regeneration of the seedlings and saplings whereas it eventually decreased the species diversity within the felling series. We found that SciFM practices increased the dominance of the intended/highvalue species. The silvicultural operations like regeneration felling followed by the postharvesting operations showed excessive growth in the seedlings and saplings density. Similarly, the regeneration promotion activities like cleaning, weeding, thinning were found suitable for establishing the regeneration of the intended species. Taking this into consideration, the CFUGs, management planners and practitioners should focus on maintaining the species diversity avoiding the excessive dominance of any single species. Hence, this study recommends the concerned authorities to adopt various measures for establishing a heterogeneous plant community under SciFM and control the risk factors that may affect regenerations. However, the reason behind the homogeneity of the species and essential measures to maintain plant species diversity should be further studied.

\section{References}

Acharya, K. P., Chaudhary, R. P. and Vetaas, O. R. (2009). Medicinal plants of Nepal: distribution pattern along an elevational gradient and effectiveness of existing protected areas for their conservation. Banko Janakari 19 (1): 16-22. https://doi. org/10.3126/banko.v19i1.2178 (Accessed on June 10, 2019).
Aryal, B., Bhattarai, B. P., Pandey, M. and Giri, A. (2017). Carbon sequestration and $\mathrm{CO}_{2}$ mitigation in a burned ecosystem of Pinus roxburghii forest in Langtang National Park, Nepal. Tropical Plant Research 4 (2): 297-306. DOI: 10.22271/tpr.2017. v4.i2.039 (Accessed on April 10, 2021).

Awasthi, N., Aryal, K., Chhetri, B. B., Bhandari, S. K., Khanal, Y., Gotame, P. and Baral, K. (2020). Reflecting on species diversity and regeneration dynamics of scientific forest management practices in Nepal. Forest Ecology and Management 474: 118378. https:// doi.org/10.1016/j.foreco.2020. 118378 (Accessed on October 11, 2021).

Awasthi, N., Bhandari, S. K. and Khanal, Y. (2015). Does scientific forest management promote plant species diversity and regeneration in Sal (Shorea robusta) forest? A case study from Lumbini collaborative forest, Rupandehi, Nepal. Banko Janakari 25 (1): 20-29. https://doi.org/10.3126/ banko.v25il.13468 (Accessed on June 10, 2019).

Baniya, B., Mandal, R. A., Adhikari, S. and Shrestha, A. (2019). Growing Stock and Regeneration Status Assessment in Thinned and Un-thinned Stands of Community Managed Pine Plantation. International Journal of Environmental Sciences \& Natural Resources 20 (1): 28-34. http:// dx.doi.org/10.19080/IJESNR.2019.20. 556030 (Accessed on April 12, 2021).

Baral, S. R. and Dhakal, S. R. (2018). Nepalma Baigyanik Ban Byabasthapan: Bartaman Abastha, Samasyara Sujhab (Scientific Forest Management in Nepal: present status, constraints and suggestions).

Baral, S., Meilby, H., Chettri, B. B. K., Basnyat, B., Rayamajhi, S. and Awale, S. (2018). Politics of getting the numbers right: Community forest inventory of Nepal. Forest Policy and Economics 91: 19-26. https:// doi.org/10.1016/j.forpol.2017.10.007 (Accessed on June 12, 2019). 
Basnyat, B., Treue, T. and Pokharel, R. K. (2018a). Silvicultural madness: a case from the "Scientific Forestry" initiative in the community forests of Nepal. Banko Janakari27 (3): 54-64. https://doi. org/10.3126/banko.v27i3.20542 (Accessed on October 9, 2021).

Basnyat, B., Treue, T., Pokharel, R. K., Lamsal, L. N. and Rayamajhi, S. (2018b). Legalsounding bureaucratic re-centralisation of community forestry in Nepal. Forest Policy and Economics 91: 5-18. https:// doi.org/10.1016/j.forpol.2017.08.010 (Accessed on Nov 21, 2020).

Bhandari, A. R. and Lamichhane, S. (2020). Sustainable Forest Management Resource Book. World Wildlife Fund, Nepal. https:// wwfasia. awsassets. panda. org/downloads/ sustainable_forest_management_ resource_book_english. pdf (Accessed date April 12, 2021).

Bhattarai, B. P., Poudyal, B. H., Acharya, R. P. and Maraseni, T. (2018). Policy and governance issues in timber harvesting: A case study on collaborative forest in Nepal. "Wild harvests, governance, and livelihoods in Asia 186.

Buffum, B., Gratzer, G. and Tenzin, Y. (2009). Forest grazing and natural regeneration in a late successional broadleaved community forest in Bhutan. Mountain Research and development 29 (1): 30-35.

Carreño Rocabado, G., Peña Claros, M., Bongers, F., Alarcón, A., Licona, J. C. and Poorter, L. (2012). Effects of disturbance intensity on species and functional diversity in a tropical forest. Journal of Ecology 100 (6): 1453-1463. https://doi.org/10.1111/ j.1365-2745.2012.02015.x (Accessed on June 12, 2019).

Cedamon, E., Nuberg, I., Paudel, G., Basyal, M., Shrestha, K. and Paudel, N. (2017). Rapid silviculture appraisal to characterise stand and determine silviculture priorities of community forests in Nepal. Smallscale Forestry 16 (2): 195-218. https:// doi.org/10.1007/s11842-016-9351-0 (Accessed on June 12, 2019).

de Avila, A. L., Ruschel, A. R., de Carvalho, J. O., Mazze, L., Silva, J. N., do Carmo Lopes, J., Araujo, M. M., Dormann, C. F. and Bauhus, J. (2015). Medium-term dynamics of tree species composition in response to silvicultural intervention intensities in a tropical rain forest. Biological Conservation 191: 577-586. https://doi.org/10.1016/j. biocon. 2015.08.004 (Accessed on June 11, 2019).

deCarvalho, A. L., d'Oliveira, M. V., Putz, F. E. and de Oliveira, L. C. (2017). Natural regeneration of trees in selectively logged forest in western Amazonia. Forest Ecology and Management 392: 36-44.

DFRS (2015). State of Nepal's Forests. Forest Resource Assessment (FRA) Nepal, Department of Forest Research and Survey, Babarmahal, Kathmandu.

DOF (2004). Community Forest Inventory Guidelines. Department of Forests, Kathmandu, Nepal.

Gautam, A. P., Webb, E. L. and Eiumnoh, A. (2002). GIS assessment of land use/ land cover changes associated with community forestry implementation in the Middle Hills of Nepal. Mountain Research and Development 22 (1): 63-69. https://doi.org/10.1659/0276-4741 (2002)022[0063:GAOLUL]2.0.CO;2 (Accessed on June 13, 2019).

Gimaret Carpentier, C., Pélissier, R., Pascal, J. P. and Houllier, F. (1998). Sampling strategies for the assessment of tree species diversity. Journal of Vegetation Science 9 (2): 161-172.http://dx.doi. org/10.2307/3237115 (Accessed on June 12, 2019). 
Giri, A., Aryal, B., Bhattarai, B., Ghimire, S. K., Shrestha, K. K. and Jha, P. K. (1999). Vegetation composition, biomass production and regeneration in Shorearobusta forests in the Royal Bardia National Park, Nepal. Nepal Journal of Science and technology 1 (1999): 47-56.

González-Alday, J., Martínez-Ruiz, C. and Bravo, F. (2008). Evaluating different harvest intensities over understory plant diversity and pine seedlings, in a Pinuspin aster Ait. natural stand of Spain. In Forest Ecology pp 211-220. https://doi. org/10. 1007/978-90-481-2795-5_16 (Accessed on June 12, 2019).

Halpern, C. B. and Spies, T. A. (1995). Plant species diversity in natural and managed forests of the Pacific Northwest. Ecological Applications 5 (4): 913-934 https://doi. org/10. 2307/2269343 (Accessed on June 12, 2019).

Hejda, M., Hanzelka, J., Kadlec, T., Štrobl, M., Pyšek, P. and Reif, J. (2017). Impacts of an invasive tree across trophic levels: species richness, community composition and resident species' traits. Diversity and Distributions 23 (9): 997-1007.

HMGN/MFSC (2002). National Biodiversity Strategy of Nepal. Ministry of Forests and Soil Conservation, His Majesty Government of Nepal.

Hull, J., Ojha, H. and Paudel, K. P. (2010). Forest inventory in Nepal-technical power or social empowerment. A. Lawrence, Taking Stock of Nature: Participatory Biodiversity Assessment for Policy, Planning and Practice, 165-184. https://doi. org/10. 1017/CBO9780511676482. 008 (Accessed on June 12, 2019).

Kawaletz, H., Mölder, I., Annighöfer, P., Terwei, A., Zerbe, S. and Ammer, C. (2014). Back to the roots: how do seedlings of native tree species react to the competition by exotic species? Annals of Forest Science 71 (3):
$337-347$.

Malik, Z. A. (2014). Phytosociological behaviour, anthropogenic disturbances and regeneration status along an altitudinal gradient in Kedarnath Wildlife Sanctuary and its adjoining areas. $\mathrm{PhD}$ desertion. Uttarakhand: HNB Garhwal University, Srinagar, Garhwal.

Malik, Z. A. and Bhatt, A. B. (2015). Phytosociological analysis of woody species in Kedarnath Wildlife Sanctuary and its adjoining areas in Western Himalaya, India. Journal of Forest and Environmental Science 31 (3): 149-163. https://doi. org/10. 7747/JFES. 2015. 31. 3. 149 (Accessed on June 12, 2019).

Malik, Z. A. and Bhatt, A. B. (2016). Regeneration status of tree species and survival of their seedlings in Kedarnath Wildlife Sanctuary and its adjoining areas in Western Himalaya, India. Tropical Ecology 57 (4): 677-690.

Malik, Z. A., Hussain, A., Iqbal, K. and Bhatt, A. B. (2014). Species richness and diversity along the disturbance gradient in Kedarnath Wildlife Sanctuary and its adjoining areas in Garhwal Himalaya, India. International Journal of Current Research 6 (12): 10918- 10926.

Margalef, R. (1958). Information theory in ecology. General Systems Yearbook 3: 36-71.

Medjibe, V. P., Poulsen, J. R., Clark, C. J. and Mbani, O. A. (2014). Natural regeneration of selected timber species in the Republic of Congo. African Journal of Ecology 52 (4): 552-563. https://doi.org/10.1111/ aje.12167 (Accessed on April 12, 2021).

Mishra, A. K., Behera, S. K., Singh, K., Chaudhary, L. B., Mishra, R. M. and Singh, B. (2013). Influence of abiotic factors on community structure of understory vegetation in moist deciduous forests of north India. Forest 
Science and Practice 15 (4): 261-273.

Mousavi, K. S., Roshani, G. A., Jalali, S. G. and Shahrdami, A. (2011). The effects of cover crown, percentage and slope aspect on the quantitative distribution of the Alders saplings in the forests of north of Iran. African Journal of Agricultural Research 6 (16): 3817-3821.doi:10.5923/j. re.20120201. 02 (Accessed on June 12, 2019).

Mwavu, E. N. and Witkowski, E. T. (2009). Seedling regeneration, environment and management in a semi-deciduous African tropical rain forest. Journal of Vegetation Science 20 (5): 791-804. http://dx. doi. org/10. 1111/j. 1654-1103. 2009. 01084. x (Accessed on June 12, 2019).

Paudel, N. S., Ojha, H., Shrestha, K., Cedamon, E., Karki, R., Paudel, G., Basyal, M., Nuberg, I. and Dangal, S. (2018). Towards active utilisation of community forestry: Silvoinstitutional model for sustainable forest management in Nepal. BankoJanakari 27 (3):120-129. https://doi. org/10. 3126/ banko. v27i3. 20557 (Accessed on Nov 22, 2020).

Paudyal, B. K. (2013). Regeneration, growth of hill sal and plant diversity in community forest: A case study from Pragatisil community forest in Kaski district, Western Nepal. BankoJanakari 23 (2): 37-43. https://doi. org/10. 3126/banko. v23i2. 15479 (Accessed on June 12, 2019).

Paudyal, D. (2007). Collaborative Forest Management in Nepal: stepping towards managing productive forests of Terai with social inclusion. The Initiation 1: 65-71.

Pokharel, R. K., Neupane, P. R., Tiwari, K. R. and Köhl, M. (2015). Assessing the sustainability in community based forestry: A case from Nepal. Forest Policy and Economics 58: 75-84. https://doi. org/10. 1016/j. forpol. 2014. 11. 006 (Accessed on June 12, 2019).
Poudel, K. C. (2018). Silviculture for forest management in Nepal. BankoJanakari 27 (3): 15-20. https://doi. org/10.3126/banko. v27i3. 20537 (Accessed on June 10,2019).

Poudyal, B. H., Maraseni, T. and Cockfield, G. (2019). Impacts of forest management on tree species richness and composition: Assessment of forest management regimes in Tarai landscape Nepal. Applied Geography 111: 102078. https://doi. org/10. 1016/j. apgeog. 2019. 102078 (Accessed on June 12, 2019).

Poudyal, B. H., Maraseni, T. and Cockfield, G. (2020). Scientific forest management practice in Nepal: Critical reflections from stakeholders' perspectives. Forests 11 (1): 27. https: //doi. org/10. 3390/f11010027 (Accessed on Oct 6, 2021).

Puhlick, J. J., Laughlin, D. C. and Moore, M. M. (2012). Factors influencing ponderosa pine regeneration in the southwestern USA. Forest Ecology and Management 264: 10-19 https://doi. org/10. 1016/j. foreco. 2011. 10. 002 (Accessed on June 11, 2019).

Roberts, M. R. and Gilliam, F. S. (1995). Patterns and mechanisms of plant diversity in forested ecosystems: implications for forest management. Ecological Applications 5 (4): 969- 977. https://doi. org/10. 2307/2269348 (Accessed on June 11, 2019).

Sakurai, T., Rayamajhi, S., Pokharel, R. K. and Otsuka, K. (2004). Efficiency of timber production in community and private forestry in Nepal. Environment and Development Economics 9 (4): 539-561. https://doi. org/10. 1017/ S1355770X04001457 (Accessed on June 13, 2019 ).

Sapkota, I. P., Tigabu, M. and Oden, P. C. (2009). Tree diversity and regeneration of community-managed Bhabar lowland and Hill Sal forests in central region of Nepal. Bois etforêts des tropiques300: 57-68. 
Sapkota, I. P., Tigabu, M. and Odén, P. C. (2010). Changes in tree species diversity and dominance across a disturbance gradient in Nepalese Sal (ShorearobustaGaertn. f. ) forests. Journal of Forestry Research 21 (1): 25-32. https://doi. org/10. 1007/ s11676-010-0004-4 (Accessed on June $13,2019)$.

Shannon, C. E., 1948. A mathematical theory of communication. The Bell System Technical Journal 27: 379-423. https://doi. org/10. 1002/j. 1538-7305. 1948. tb01338. x (Accessed on June 13, 2019).

Shima, K., Yamada, T., Okuda, T., Fletcher, C. and Kassim, A. R. (2018). Dynamics of tree species diversity in unlogged and selectively logged Malaysian Forests. Scientific reports 8 (1): 1-8. https:// doi. org/10. 1038/s41598-018-19250-Z (Accessed on Nov6, 2020).

Smith, R. G., Nichols, J. D. and Vanclay, J. K. (2005). Dynamics of tree diversity in undisturbed and logged subtropical rainforest in Australia. Biodiversity \& Conservation 14 (10): 2447-2463. https:// doi. org/10. 1007/s10531-004-0215-0 (Accessed on June 12, 2019).

Subedi, B. P., Pandey, S. S., Pandey, A., Rana, E. B., Bhattarai, S., Banskota, T. R., Charmakar, S. and Tamrakar, R. (2010). Forest carbon stock measurement: guidelines for measuring carbon stocks in community-managed forests. Kathmandu: Asia Network for Sustainable Agriculture and Bioresources (ANSAB), Federation of Community Forestry Users Nepal (FECOFUN), International Centre for Integrated Mountain Development (ICIMOD).
Subedi, V. R., Bhatta, K. D., Poudel, I. P. and Bhattarai, P. (2018). Application of silvicultural system, yield regulation and thinning practices in natural forests: case study from western Terai. BankoJanakari 27 (3): 92-97. https://doi. org/https:// doi. org/10. 3126/banko. v 27i3. 20553 (Accessed on April 12, 2021).

Sunam, R. K., Paudel, N. S. and Paudel, G. (2013). Community forestry and the threat of recentralization in Nepal: contesting the bureaucratic hegemony in policy process. Society \& Natural Resources 26 (12): 1407-1421. https://doi. org/10. 1080/ 08941920. 2013. 799725 (Accessed on June 13, 2019).

Uniyal, P., Pokhriyal, P., Dasgupta, S., Bhatt, D. and Todaria, N. P. (2010). Plant diversity in two forest types along the disturbance gradient in Dewalgarh Watershed, Garhwal Himalaya. Current Science 10: 938-943. https://www. jstor. org/stable/24111551 (Accessed on June 12, 2019).

Yadav, N. P., Dev, O. P., Springate-Baginski, O. and Soussan, J. (2003). Forest management and utilization under community forestry. Journal of Forest and Livelihood 3 (1): $37-50$.

Yang, X., Yan, D. and Liu, C. (2014). Natural regeneration of trees in three types of afforested stands in the Taihang Mountains, China. PLoS ONE 9 (9): e108744 https:// doi. org/10. 1371/journal. pone. 0108744 (Accessed on June 12, 2019 ). 